\title{
Chemical composition and energetic values of wheat and its sub-products for broiler chicken
}

\section{Composição química e valores energéticos do trigo e seus subprodutos para frangos de corte}

\author{
Jomara Broch $^{1 *}$; Newton Tavares Escocard de Oliveira ${ }^{2}$; \\ Ricardo Vianna Nunes ${ }^{2}$; Jeffersson Rafael Henz ${ }^{3}$; Idiana Mara da Silva ${ }^{4}$; \\ Rafael Frank ${ }^{3}$; Rodrigo André Schone ${ }^{3}$
}

\begin{abstract}
The objective of this study was to determine the chemical composition, apparent metabolizable energy $(\mathrm{AME}), \mathrm{AME}$ corrected by nitrogen retention $\left(\mathrm{AME}_{\mathrm{n}}\right)$ and metabolization coefficients $\left(\mathrm{MC}\right.$ and $\left.\mathrm{MC}_{\mathrm{n}}\right)$ of different feeds for broilers from the western region of Paraná State. The experiment was conducted at the Physiology of Birds Laboratory at UNIOESTE. Two hundred and sixty male chicks of the Cobb 500 strain, at 21 days old, were distributed in a randomized design with 12 treatments and four replicates of five birds per experimental unit. The feed ingredients studied were ten different wheat middlings, one triticale, one wheat grain and a reference diet. Values for dry matter, nitrogen, gross energy, neutral detergent fiber, acid detergent fiber, mineral matter, calcium, phosphorus, sodium, potassium and magnesium composition were determined as well as the geometric mean diameter of the feed particles. To determine the apparent metabolizable energy (AME) and AME corrected for nitrogen balance $\left(\mathrm{AME}_{\mathrm{n}}\right)$ the total excreta collection method was used with growing birds. The chemical composition of the feeds was variable. The values for $\mathrm{AME}$ and $\mathrm{AME}_{\mathrm{n}}$ ranged from 1. 819-2. 958 and 1.734-2. 882 $\mathrm{kcal} . \mathrm{kg}^{-1}$, respectively. Based on these energetic values and the values for gross energy, the coefficients of metabolizability were calculated. The values ranged from 43. 26-75. $24 \%$ for $\mathrm{MC}$ and from 42. 2873. $31 \%$ for $\mathrm{MC}_{\mathrm{n}}$.
\end{abstract}

Key words: Alternative foods, poultry, digestibility

\section{Resumo}

O objetivo deste trabalho foi determinar a composição química e os valores de energia metabolizável aparente (EMA), EMA corrigida pela retenção de nitrogênio $\left(\mathrm{EMA}_{\mathrm{n}}\right)$ e seus respectivos coeficientes de metabolizabilidade $\left(\mathrm{CMA}\right.$ e $\mathrm{CMA}_{\mathrm{n}}$ ) de diferentes alimentos para frangos de corte provenientes da região oeste do Estado do Paraná. O experimento foi realizado no Laboratório de Fisiologia de Aves da UNIOESTE. Foram utilizados 260 pintos de corte machos, da linhagem Cobb 500, com 21 dias de idade, distribuídos em um delineamento inteiramente casualizado, com doze tratamentos, quatro repetições e cinco aves por unidade experimental. Os ingredientes estudados foram dez diferentes

1 Discente do Curso de Mestrado em Zootecnia, Universidade Estadual do Oeste do Paraná, UNIOESTE, PPZ, Marechal Cândido Rondon, PR, Brasil. E-mail: brochjomara@yahoo.com.br

2 Profs., UNIOESTE, CCA, PPZ, Marechal Cândido Rondon, PR, Brasil. E-mail: newtonescocard@hotmail.com; nunesrv@, hotmail.com

3 Mestres em Zootecnia, UNIOESTE, PPZ, Marechal Cândido Rondon, PR, Brasil. E-mail: jefferson_henz@hotmail.com; rafaelfrankrafael@hotmail.com; kiko_schone@hotmail.com

4 Discente do Curso de Graduação em Zootecnia, UNIOESTE, PPZ, Marechal Cândido Rondon, PR, Brasil. E-mail: idianams@, outlook.com

* Author for correspondence 
farelos de trigo, um triticale, um trigo grão e uma ração referência. Foram determinados valores de matéria seca, nitrogênio, energia bruta, fibra em detergente neutro, fibra em detergente ácido, matéria mineral, cálcio, fósforo, sódio, potássio e magnésio e o valor do diâmetro geométrico médio. Para determinação dos valores de EMA e EMA foi utilizado o método de coleta total de excretas com aves em crescimento. A composição química dos alimentos estudados apresentaram variações. Os valores de EMA e EMA variaram de 1819 a 2958 e 1734 a $2882 \mathrm{kcal} / \mathrm{kg}$, respectivamente. De acordo com os valores energéticos e energia bruta, foram calculados os coeficientes de metabolizabilidade, valores estes que variaram de 43,26 a 75,24\% para CMA e de 42,28 a 73,31\% para $\mathrm{CMA}_{\mathrm{n}}$.

Palavras-chave: Alimentos alternativos, aves, digestibilidade

\section{Introduction}

The determination of the energetic and chemical composition of the ingredients used in feed formulations is critical in order to provide a diet with accurate nutritional composition at minimal production cost. Cereal grains are a rich source of carbohydrates and are responsible for supplying most of the energy in the feed for broilers. Therefore, the digestion and utilization qualities of the grains are important (STAMMEN, 2010).

Despite the constant search for alternative foods that can reduce production costs, rations are mainly formulated using corn and soybean meal. However, due to the high price of corn, especially during the off-season, possible alternative sources have become viable. Based on nutritional value and availability, nutritionists have shown interest in wheat, triticale and their by-products.

Wheat is widely used in the poultry industry in European countries (BARTECZKO et al., 2009). Its nutritional potential in feeding birds is not well known due to the variability of energy values among its cultivars (CARRÉ et al., 2007). Triticale is obtained by artificially crossing wheat with rye, and has a higher protein and lower fiber content compared with wheat bran.

However, the availability of nutrients in these feed components is influenced by anti-nutritional factors present in the grain (non-starch polysaccharides, trypsin inhibitors and chymotrypsin) that negatively affect the use of energy by birds (ARAÚJO, 2007). Furthermore, the amount of energy provided by the grain can also vary according to the amount of food consumed and the degree of extension of the bird's digestive tract (BLACK et al., 2005). The amount of food consumed by the birds affects the nutrient application needed to meet their metabolic demands, since the volume of the digestive tract and the rate of passage of digesta affect the efficiency of digestion of food and absorption of nutrients. These factors emphasize the importance of determining the chemical and energetic composition of feed ingredients (TACHIBANA et al., 2010).

Thus, this study was conducted to evaluate the chemical composition, $\mathrm{AME}, \mathrm{AME}_{\mathrm{n}}$ and the associated $\mathrm{MC}$ and $\mathrm{MC}_{\mathrm{n}}$, of ten different wheat brans, one triticale and one grain wheat, using a digestibility trial with birds in the growth phase.

\section{Materials and Methods}

The experiment was conducted at the Laboratory of Physiology and Experimental Station for Poultry Metabolism, State University of Paraná West UNIOESTE. Ten wheat brans (WB), one triticale (TT) and one wheat grain (WG) from different flour mills of Western Paraná were analyzed.

Two hundred and sixty male broiler chicks of the Cobb 500 strain were used at 21 days old, with an average body weight of $935.67 \pm 13.96$ grams, distributed in a randomized design using 12 treatments and four replicates of five birds per experimental unit. The experimental diets were composed of: the reference diet (RR) (Table 1), formulated to meet the requirements of animals 2232 days of age, according to the recommendations of Rostagno et al. (2011); ten test diets replacing 
$20 \%$ of the feed with wheat bran (WB); and two test diets replacing $30 \%$ of the feed with triticale (TT) or wheat grain (WG).

The chemical analyses of food were performed at the Animal Nutrition Laboratory of UNIOESTE. Dry matter (DM), nitrogen $(\mathrm{N})$, gross energy (GE), neutral detergent fiber (NDF), acid detergent fiber
(ADF), mineral matter (MM), calcium, phosphorus, sodium, potassium and magnesium composition were determined according to Silva and Queiroz (2002). The geometric mean diameter (GMD) of the feed particles was determined according to the methodology proposed by Zanotto and Bellaver (1996).

Table 1. Composition of reference diet (RR) expressed as percentage of dry matter.

\begin{tabular}{|c|c|}
\hline Ingredient & $(\%)$ \\
\hline Corn & 63.42 \\
\hline Soybean Meal 45\% & 31.52 \\
\hline Soybean oil & 1.51 \\
\hline Limestone & 0.91 \\
\hline Dicalcium phosphate & 1.62 \\
\hline Salt & 0.36 \\
\hline L-lysine HCL (78\%) & 0.11 \\
\hline DL-Methionine (99\%) & 0.18 \\
\hline Choline chloride $(60 \%)$ & 0.06 \\
\hline Mineral supplement ${ }^{1}$ & 0.07 \\
\hline Vitamin supplement ${ }^{2}$ & 0.12 \\
\hline Anticoccidial $^{3}$ & 0.05 \\
\hline Growth promoter ${ }^{4}$ & 0.05 \\
\hline Antioxidant $^{5}$ & 0.02 \\
\hline \multicolumn{2}{|l|}{ Calculated composition (\%) } \\
\hline Metabolizable Energy (kcal/kg) & 3.000 \\
\hline Protein & 19.50 \\
\hline Calcium & 0.870 \\
\hline Available phosphorus & 0.41 \\
\hline Digestible lysine & 1.04 \\
\hline Digestible methionine & 0.46 \\
\hline Methionine + cystine & 0.73 \\
\hline Digestible tryptophan & 0.22 \\
\hline Digestible threonine & 0.67 \\
\hline Sodium & 0.19 \\
\hline
\end{tabular}

': mineral supplement content $\mathrm{Mg}-16.0 \mathrm{~g} ; \mathrm{Fe}-100.0 \mathrm{~g} ; \mathrm{Zn}-100.0 \mathrm{~g} ; \mathrm{Cu}-2.0 \mathrm{~g}, \mathrm{Co}-2.0 \mathrm{~g} ; \mathrm{I}-2.0 \mathrm{~g} ;$ and vehicle q. s. p. -1. $000 \mathrm{~g}$.

${ }^{2}$ vitamin supplement content: Vitamin A - 10. 000. 000 UI; Vitamin D3 - 2. 000. 000 UI; Vitamin E - 30. 000 UI; Vitamin B1 - 2. $0 \mathrm{~g}$; Vitamin B6 - $4.0 \mathrm{~g}$; Acid pantothenic - $12.0 \mathrm{~g}$; biotin - $0.10 \mathrm{~g}$; Vitamin K3 - $3.0 \mathrm{~g}$; Acid folic - $1.0 \mathrm{~g}$; Acid Nicotílico - 50 . $0 \mathrm{~g}$; Vitamin B12 - 15. $000 \mathrm{mcg}$; selenium - 0. $25 \mathrm{~g}$; and vehicle q. s. p. $-1.000 \mathrm{~g}$.

${ }^{3}$ salinomycin $-12 \% ;{ }^{4}$ avilamycin $-10 \% ;{ }^{5}$ BHT (Butylated Hydroxytoluene).

To determine the apparent metabolizable energy (AME) and nitrogen-corrected apparent metabolizable energy $\left(\mathrm{AME}_{\mathrm{n}}\right)$ of the feed, we used the total collection of excreta method with growing chickens (SIBBALD; SLINGER, 1963). From one until 21 days of age the birds were raised in a brick shed at the poultry sector of UNIOESTE, with under-floor maravalha receiving an initial ration formulation based on corn and soybean meal. All groups received food and water ad libitum until 21 days of age. 
The experiment lasted ten days, with five days of adaptation and five days of total excreta collection. Collection was performed twice a day, with an interval of 12 hours, to prevent fermentation. In the collection period, trays were covered with plastic and placed under the cages to avoid loss and contamination. The excreta were placed in plastic bags and stored at $-18{ }^{\circ} \mathrm{C}$. At the end of the trial period the feed intake and the total amount of excreta produced by each experimental unit were determined.

Excreta were thawed, homogenized and weighed. A known weight of each replicate sample was predried in a forced-ventilation oven for 72 hours at 55 ${ }^{\circ} \mathrm{C}$. The samples were then ground and the DM, GE and $\mathrm{N}$ analyses were performed.

Using the results of the analysis of the experimental feeds, reference diet (RR) and excreta, values for $\mathrm{AME}$ and $\mathrm{AME}_{\mathrm{n}}$ were calculated according to the equations proposed by Matterson et al. (1965). The metabolization coefficients of crude energy were calculated from the values of AME and $\mathrm{AME}_{\mathrm{n}}$ according to Leeson and Summers (2001).

The Student- Newman- Keuls (SNK) test at 5\% probability was applied to compare the mean values of the metabolization coefficient of AME (MC) and the metabolization coefficient of $\operatorname{AME}_{n}\left(M_{n}\right)$ for the different feeds studied. This procedure was performed using the Statistical and Genetic Analysis System - SAEG (UNIVERSIDADE FEDERAL DE VIÇOSA - UFV, 1999).

\section{Results and Discussion}

The differences in the chemical parameters of the feeds studied (Table 2) may be due to environmental conditions, varietal differences and the types of processing to which the grains are subjected. Food processing affects the chemical composition, nutritional value and digestibility of nutrients by the animal and therefore may interfere with performance (OMS, 2009).

Table 2. Chemical composition of different foods by percentage of dry matter.

\begin{tabular}{|c|c|c|c|c|c|c|c|c|c|c|c|c|}
\hline \multirow{2}{*}{$\begin{array}{c}\text { Nutrients } \\
(\%)\end{array}$} & \multicolumn{12}{|c|}{ Food } \\
\hline & WB-1 & WB-2 & WB-3 & WB-4 & WB-5 & WB-6 & WB-7 & WB-8 & WB-9 & WB-10 & $\mathrm{TT}$ & WG \\
\hline $\mathrm{DM}$ & 87.83 & 87.37 & 89.11 & 88.72 & 88.46 & 88.15 & 87.71 & 88.65 & 89.21 & 88.33 & 87.17 & 87.29 \\
\hline $\mathrm{CP}$ & 19. 29 & 17. 59 & 17.04 & 16.68 & 16. 82 & 18.44 & 18.22 & 16. 51 & 16.67 & 17. 16 & 16. 50 & 14.69 \\
\hline $\mathrm{EE}$ & 2.25 & 1. 91 & 2. 83 & 3. 14 & 2.97 & 3.04 & 2. 42 & 3.34 & 3.27 & 2.97 & 1. 13 & 1. 17 \\
\hline $\mathrm{ADF}$ & 8.97 & 8. 11 & 9.74 & 8. 14 & 9.31 & 10.65 & 8.98 & 10.93 & 9.92 & 11.31 & 5.53 & 4. 76 \\
\hline NDF & 38.48 & 31.18 & 36.02 & 30.27 & 32.82 & 37.74 & 32.12 & 37.10 & 42.75 & 47.70 & 42.68 & 34.93 \\
\hline MM & 3.05 & 3. 84 & 3.96 & 4. 55 & 3. 86 & 3.76 & 2.95 & 4. 00 & 3.19 & 3. 66 & 2. 60 & 1. 61 \\
\hline GMD $(\mu \mathrm{m})$ & 2630 & 2120 & 1662 & 1428 & 2311 & 2309 & 1843 & 1759 & 2383 & 1652 & 1231 & 996 \\
\hline
\end{tabular}

$\mathrm{WB}=$ wheat bran; $\mathrm{TT}=$ triticale; $\mathrm{WG}=$ wheat grain; $\mathrm{DM}=$ dry matter; $\mathrm{CP}=$ crude protein; $\mathrm{EE}=$ ether extract; $\mathrm{MM}=$ mineral matter; $\mathrm{NDF}=$ neutral detergent fiber; $\mathrm{ADF}=$ acid detergent fiber; GMD = geometric mean diameter.

The crude protein of the evaluated ingredients ranged from 14. 69-19. 29\%. The CP values for wheat bran were close to those of Generoso et al. (2008) and Silva et al. (2009), who found values of 15. $12 \%$ and $14.48 \%$, respectively. The variation in the CP content of the ingredients may be related to the increased amount of starch from the grain endosperm acquired during the extraction step.

Mineral matter (MM) composition of the different feeds studied ranged from 1. 61-4. 55\%, values lower than reported by Silva et al. (2009), who found MM of 5. 44\% for wheat bran. However, 
a similar value was found by Generoso et al. (2008).

Ether extract ranged from 1. 13-3. 34\% in dry matter. The values found are similar compared to those found in the literature in studies evaluating wheat (ARAÚJO et al., 2008; MELLO et al., 2009).

The neutral detergent fiber (NDF) content of the foods studied ranged from 30. 27-47. 70\%. These results were similar to those obtained by Generoso et al. (2008) and Silva et al. (2009), who found values of $38.38 \%$. High fiber content can affect the rate of passage of food through the gastrointestinal tract, and thus interfere with the use of nutrients (SILVA et al., 2002) and consequently the performance of the animals. Brum et al. (2000) found a negative effect of diets containing $40 \%$ wheat on the performance of broiler chickens.

The particle size of feed ingredients affects the digestibility and density of nutrients. It influences food intake and digestion of food by altering the anatomy of the digestive tract and/or digestive secretions (RIBEIRO et al., 2002; NIR et al., 1994). Zanotto and Bellaver (1996) classified foods with GMD above 832.7 microns as coarse; those with GMD between 375.3 and 832.7 microns as average; and those with GMD less than 375.7 micrometers as fine. The foods studied in this work varied from 996-2630 microns, and are thus classified as coarse. NUNES et al. (2001) studied different wheat brans and found lower values, ranging from 523-983 microns. These variations are due to different grain characteristics and different degrees of milling particular to the factory in which the grain was processed. Factories generate several by-products, such as fine bran and bran, which may be included to a varying degree in the final product, wheat bran (WESENDONCK, 2012). These quality problems in the processing industry show the importance of performing a standardization or classification of final waste wheat.

Gross energy (GE) values (Table 3) ranged from $3889-4369 \mathrm{kcal} / \mathrm{kg}$ in the dry matter. MN, and similar values are found in the literature (GENEROSO et al., 2008; MELLO et al., 2009; SILVA et al., 2009). The energy values can be influenced by physical characteristics related to soluble fiber content and viscosity when the feed grain is dissolved. These include the capacity of soluble fiber to absorb water and form a gel-like substance in the intestinal tract, thus hindering digestion (BRITO et al., 2008); and bromatological characteristics related to the content of $\mathrm{CP}$ and the profile of fatty acids, amino acids and minerals of the feed ingredients (LASEK et al., 2011; NUNES et al., 2005). Among the nutrients that can affect the energy content of food, ether extract is positively correlated with the energy values. However, the mineral matter and fiber correlate negatively. High levels of mineral matter mean lower levels of organic matter, which is responsible for the production of energy (NASCIMENTO et al., 2009). Fiber negatively affects the available energy by increasing the speed of passage of food through the gastrointestinal tract (SANTOS et al., 2005). In a study by Lasek et al. (2011) different cultivars of Polish wheats differ in chemical composition, but these differences did not affect the GE the amino acid profile or the fatty acid composition.

In general, the AME values of feedstuffs were higher than the $\mathrm{AME}_{\mathrm{n}}$ values (Table 3). This usually occurs when the metabolism assays are performed with birds in the growth phase due to higher nitrogen retention during deposition of protein tissue, and the difference becomes more pronounced when the values are corrected for metabolic and endogenous losses (NERY et al., 2007).

The AME values obtained in this assay for the various feed ingredients studied ranged from $1819-2958 \mathrm{kcal} / \mathrm{kg}$ in the dry matter. Nunes et al. (2001) obtained values of 1807-1940 kcal / kg, MN and Generoso et al. (2008) $1820 \mathrm{kcal} / \mathrm{kg}, \mathrm{MN}$. However, Mello et al. (2009) reported a lower value (1624 kcal / kg, MN) and Silva et al. (2009) a higher one $(2088 \mathrm{kcal} / \mathrm{kg}, \mathrm{MN})$ than those obtained in the present study. In a study by Barteczko et al. (2009), no differences were found in AME values between different wheat cultivars. 


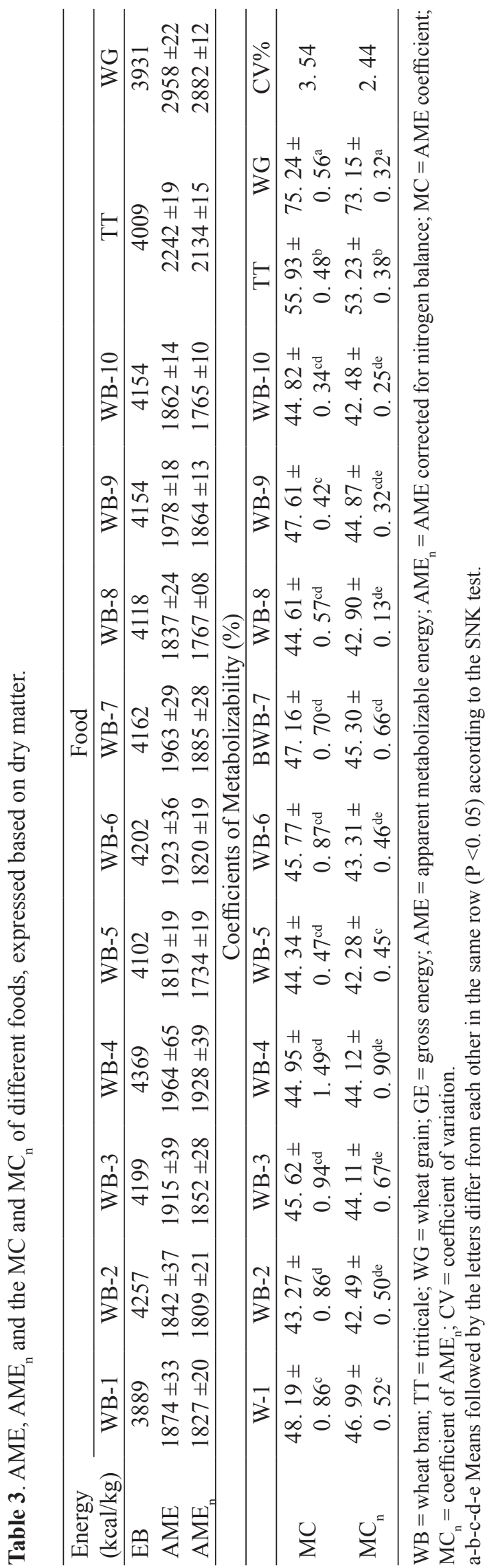

The values of $\mathrm{AME}_{\mathrm{n}}(1734-2882 \mathrm{kcal} / \mathrm{kg}, \mathrm{MN})$ for the feed ingredients in this study were similar to those cited by Nunes et al. (2001) and Silva et al. (2009), values from 1758-1936 and $1919 \mathrm{kcal} / \mathrm{kg}$, MN, respectively. Generoso et al. (2008), and Mello et al. (2009) reported lower values at 1683 and 1621 $\mathrm{kcal} / \mathrm{kg}$ in the dry matter.

The variation of the energy values found in this study is due to differing chemical composition of the feed ingredients, as energy results from the oxidation of nutrients during metabolism. According to Smits and Annison (1996), negative correlations between the fiber content and the energy value of foods are explained by the presence of soluble non-starch polysaccharides, which adversely affects the ability of birds to digest certain nutrients, especially starch, protein and fat, leading to reduced absorption of nutrients and reducing the energy value.

There were significant differences $(\mathrm{P}<0$. 05) between the metabolization coefficients of the ingredients tested. The wheat grain had the highest coefficient of metabolizability, probably due to the lower particle size (GMD). According to Brugalli (1996), differences in GMD influence energy values. Reducing the size of the particles contributes to better digestion and absorption of nutrients through increased surface exposure to the action of digestive enzymes. Consequently, the smaller diameter of the particles contributes to the better performance of chickens because of better digestibility of the feed (AMERAH et al., 2007).

Counteracting the effect of reduced particle size, factors such as high fiber (FB, NDF, ADF) and the presence of soluble non-starch polysaccharides (such as hemicellulose, pectin, $\beta$-glucan, fructosans) that increase the viscosity of the digesta and hinder digestion enzymes can interfere with the use of raw energy as metabolizable energy. Thus, the feed content of starch, fat and protein is positively correlated with the energy values, the structural carbohydrates correlating negatively (CONTE et al., 2002). According to Araújo (2007), wheat 
bran and its derivatives contain pentosans, trypsin inhibitors and chymotrypsin, as well as crude fiber. The levels of these anti-nutritional factors found in wheat brans interfere with digestion and absorption of nutrients and explain their low levels of energy.

Due to variations in the composition of feed ingredients, knowledge about their chemical composition and energy content is necessary in order to achieve greater accuracy in feed formulations.

\section{Conclusion}

The values of $A M E$ and $\mathrm{AME}_{\mathrm{n}}$ obtained for the wheat products in this study ranged from 1819-2958 and from 1734-2882 kcal / kg in MN, respectively. The associated coefficients of metabolization, $\mathrm{MC}$ and $\mathrm{MC}_{\mathrm{n}}$ for the studied feed ingredients ranged from 42. 28-73. $31 \%$ and from 43. 26-75. 24\%, respectively.

\section{References}

AMERAH, A. M.; RAVINDRAN, V.; LENTLE, R. G.; THOMAS, D. G. Influence of feed particle size and feed form on the performance, energy utilization, digestive tract development, and digesta parameters of broiler starters. Poultry Science, Champaign, v. 86, n. 12, p. 2615-2623, 2007.

ARAÚJO, D. M.; SILVA, J. H.; ARAÚJO, J. A.; RIBEIRO, M. L. G.; PASCOL, L. A. F.; COSTA, F. G. P. Farelo de trigo e complexo enzimático na alimentação de frangas de reposição. Ciência e Agrotecnologia, Lavras, v. 32, n. 6, p. 1960-1967, 2008.

ARAÚJO, W. A. G. Alimentos energéticos alternativos para suínos. Revista Eletrônica Nutritime, Viçosa, v. 4, n. 1, p. 384-394, 2007.

BARTECZKO, J.; AUGUSTYN, R.; LASEK, O.; SMULIKOWSKA, S. Chemical composition and nutritional value of different wheat cultivars of broiler chickens. Journal of Animal and Feed Sciences, Poland, v. 18, n. 1, p. 124-131, 2009.

BLACK, J. L.; HUGHES, R. J.; NIELSEN, S. G.; TREDREA, A. M.; MacALPINE, R.; BARNEVELD, R. J. The energy value of cereal grains, particular wheat and sorghum, for poultry. Australian Poultry Science Symposium, Champaign, v. 17, n. 1, p. 21-29, 2005.
BRITO, M. S.; OLIVEIRA, C. F. S.; SILVA, T. R. G.; LIMA, R. B.; MORAIS, S. N.; SILVA, J. H. V. Polissacarídeos não amiláceos na nutrição de monogástricos: revisão. Acta Veterinaria Brasilica, Mossoró, v. 2, n. 4, p. 111-117, 2008.

BRUGALLI, I. Efeito da granulometria na biodisponibilidade de fósforo e nos valores energéticos da farinha de carne e ossos e exigência nutricional de fósforo para pintos de corte. 1996. Dissertação (Mestrado em Zootecnia) - Universidade Federal de Viçosa, Viçosa, MG.

BRUM, P. A. R.; ZANOTTO, D. L.; LIMA, G. J. M. M.; VIOLA, E. S. Composição química e energia metabolizável de ingredientes para aves. Pesquisa Agropecuária Brasileira, Brasília, v. 35, n. 5, p. 995 $1002,2000$.

CARRÉ, B.; GRASTEAU, S. M.; PÉRON, A.; JUIN, H.; BASTIANELLI, D. Wheat value: improvements by feed technology, plant breeding and animal genetics. World Poultry Science Journal, Montpellier, v. 63, n. 4, p. 188194, 2007.

CONTE, A. J.; TEIXEIRA, A. S.; BERTECHINI, A. G. Efeito da fitase e xilanase sobre a energia metabolizável do farelo de arroz integral em frangos de corte. Ciência e Agrotecnologia, Lavras, v. 26, n. 6, p. 1289-1296, 2002.

GENEROSO, R. A. R.; GOMES, P. C.; ROSTAGNO, H. S.; ALBINO, L. F. T.; BARRETO, S. L. T.; BRUMANO, G. Composição química e energética de alguns alimentos para frangos de corte em duas idades. Revista Brasileira de Zootecnia, Viçosa, MG, v. 37, n. 7, p. 1251-1256, 2008.

LASEK, O.; BARTECZKO, J.; AUGUSTYN, R.; SMULIKOWSKA, S.; BOROWIEC, F. Nutritional and energy value of wheat cultivars for broiler chickens. Journal of Animal and Feed Sciences, Poland, v. 20, n. 2, p. 246-258, 2011.

LEESON, S.; SUMMERS, J. D. Scott's nutrition of the chicken. Guelph: Canadá University Books, 2001. 591 p.

MATTERSON, L. D.; POTTER, L. M.; STUTZ, M. W. The metabolizable energy offeed ingredients for chickens. Storrs, Connecticut: The University of Connecticut, Agricultural Experiment Station, 1965. $11 \mathrm{p}$.

MELLO, H. H. C.; GOMES, P. C.; ROSTAGNO, H. S.; ALBINO, L. F. T.; SOUZA, R. M.; CALDERANO, A. A. Valores de energia metabolizável de alguns alimentos obtidos com aves de diferentes idades. Revista Brasileira de Zootecnia, Viçosa, MG, v. 38, n. 5, p. 863-868, 2009. 
NASCIMENTO, G. A. J.; RODRIGUES, P. B.; FREITAS, R. T. F.; BERTECHINI, A. G.; LIMA, R. R.; PUCCI, L. E. A. Equações de predição para estimar os valores energéticos de alimentos concentrados de origem vegetal para aves utilizando a metanálise. Revista Brasileira de Zootecnia, Viçosa, MG, v. 38, n. 7, p. 1265-1271, 2009.

NERY, L. R.; ALBINO, L. F. T.; ROSTAGNO, H. S.; CAMPOS, A. M. A.; SILVA, C. R. Valores de energia metabolizável de alimentos determinados com frangos de corte. Revista Brasileira de Zootecnia, Viçosa, MG, v. 36, n. 5, p. 1354-1358, 2007.

NIR, I.; HILEL, R.; SHEFET, G.; NITSAN, Z. Effect of grain particle size on performance. Grain texture interactions. Poultry Science, Champaign, v. 73, n. 6, p. 781-791, 1994.

NUNES, R. V.; POZZA, P. C.; NUNES, C. G. V.; CAMPESTRINI, E.; KUHL, R.; ROCHA, L. D.; COSTA, F. G. P. Valores energéticos de subprodutos de origem animal para aves. Revista Brasileira de Zootecnia, Viçosa, MG, v. 34, n. 4, p. 1217-1224, 2005.

NUNES, R. V.; ROSTAGNO, H. S.; ALBINO, L. F. T.; GOMES, P. C.; TOLEDO, R. S. Composição bromatológica, energia metabolizável e equações de predição da energia do grão e de subprodutos do trigo para pintos de corte. Revista Brasileira de Zootecnia, Viçosa, MG, v. 30, n. 3, p. 785-793, 2001.

OMS, G. A. Factors affecting wheat nutritional value for broiler chickens. 2009. Tese (Doutorado em Ciência Animal) - Wageningen University, Madrid.

RIBEIRO, A. M. L.; MAGRO, N.; PENZ JÚNIOR, A. M. Granulometria do milho em rações de crescimento de frangos de corte e seu efeito no desempenho e metabolismo, Revista Brasileira de Ciência Avícola, Campinas, v. 4, n. 1, p. 47-53, 2002.

ROSTAGNO, H. S.; ALBINO, L. F. T.; DONZELE, J. L.; GOMES, P. C.; OLIVEIRA, R. F.; LOPES, D. C.; FERREIRA, A. S.; BARRETO, S. L. T.; EUCLIDES, R. F. Tabela brasileira para aves e suínos: composição de alimentos e exigência nutricional. Viçosa: UFV, Departamento de Zootecnia, 2011. 186 p.

SANTOS, Z. A. S.; FREITAS, R. T. F.; FIALHO, E. T.; RODRIGUES, P. B.; LIMA, J. A. F.; CARELLOS, D. C.; BRANCO, P.A. C.; CANTARELLI, V.S. Valor nutricional de alimentos para suínos determinado na Universidade Federal de Lavras. Ciência e Agrotecnologia, Lavras, v. 29, n. 1, p. 232-237, 2005.
SIBBALD, I. R.; SLINGER, S. J. A biological assay for metabolizable energy in poultry feed ingredients together with findings which demonstrate some of the problems associated with the evaluation of fats. Poultry Science, Champaing, v. 59, n. 2, p. 1275-1279, 1963.

SILVA, D. J.; QUEIROZ, A. C. Análise de alimentos: métodos químicos e biológicos. Viçosa, MG: UFV, 2002. $235 \mathrm{p}$.

SILVA, E. P.; RABELLO, C. B.; LIMA, M. B.; LIMA, M. B.; LOUREIRO, R. R. S.; GUIMARÃES, A. A. S.; DUTRA JÚNIOR, W. M. Valores energéticos de ingredientes convencionais para aves de postura comercial. Ciência Animal Brasileira, Goiânia, v. 10, n. 1, p. 91-100, 2009.

SILVA, J. H. V.; SILVA, E. L.; JORDÃO FILHO, J.; TOLEDO, R. S.; ALBINO, L. F. T.; RIBEIRO, M. L. G.; COUTO, H. P. Valores energéticos e efeitos da inclusão da farinha integral da vagem de algaroba (Prosopis juliflora (Sw.) D. C.) em rações de poedeiras comerciais. Revista Brasileira de Zootecnia, Viçosa, MG, v. 31, n. 6, p. 2255-2264, 2002.

SMITS, C. H. M.; ANNISON, G. Non-starch plant polysaccarides in broiler nutrition - towards a physiological valid approach to their determination. World Poultry Science Journal, Cambridge, v. 52, n. 2, p. 203-221, 1996.

STAMMEN, B. Feed preference index on cereal grains for poultry. [S.1]: The Ohio State University, 2010.

TACHIBANA, L.; GONÇALVES, G. S.; GUIMARÃES, I. G.; FALCON, D. R.; BARROS, M.; PEZZATO, L. E. Substituição do milho pelo triticale na alimentação de tilápias-do-nilo. Revista Brasileira de Zootecnia, Viçosa, MG, v. 39, n. 2, p. 241-246, 2010.

UNIVERSIDADE FEDERAL DE VIÇOSA - UFV. Manual de utilização do programa SAEG: sistema para análise estatísticas e genéticas. Viçosa: UFV, 1999. 59 p.

WESENDONCK, W. R. Valor nutricional de diferentes subprodutos do trigo para suínos em crescimento. 2012. Dissertação (Mestrado em Zootecnia) - Universidade Federal do Rio Grande do Sul, Porto Alegre.

ZANOTTO, D. L.; BELLAVER, C. Método de determinação da granulometria de ingredientes para uso em rações de suínos e aves. Concórdia: EMBRAPA aves e suínos, 1996. 5 p. (Comunicado técnico, n. 215). 